\title{
Chapter 8 \\ Traditional and Adapted Composting \\ Practices Applied in Smallholder Banana- \\ Coffee-Based Farming Systems: Case \\ Studies from Kagera and Morogoro \\ Regions, Tanzania
}

\author{
Anika Reetsch, Didas Kimaro, Karl-Heinz Feger, and Kai Schwärzel
}

\begin{abstract}
In Tanzania, about $90 \%$ of the banana-coffee-based farming systems lie in the hands of smallholder farmer families. In these systems, smallholder farmers traditionally add farm waste to crop fields, making soils rich in organic matter (humus) and plant-available nutrients. Correspondingly, soils remained fertile during cultivation for over a century. Since the 1960s, the increasing demand for food and biofuels of a growing population has resulted in an overuse of these farming systems, which has occurred in tandem with deforestation, omitted fallows, declined farm size, and soil erosion. Hence, humus and nutrient contents in soils have decreased and soils gradually degraded. Inadequate use of farm waste has led to a further reduction in soil fertility, as less organic material is added to the soils for nutrient supply than is removed during harvesting. Acknowledging that the traditional use of farm waste successfully built up soil fertility over a century and has been reduced in only a few decades, we argue that traditional composting practices can play a key role in rebuilding soil fertility, if such practices are adapted to face
\end{abstract}

\footnotetext{
A. Reetsch $(\square)$

Institute for Integrated Management of Material Fluxes and of Resources (UNU-FLORES), Dresden, Germany

Sebastian Kolowa Memorial University, Lushoto, Tanzania e-mail: reetsch@unu.edu

D. Kimaro

Sebastian Kolowa Memorial University, Lushoto, Tanzania

K.-H. Feger

Technische Universität Dresden, Dresden, Germany

e-mail: karl-heinz.feger@tu-dresden.de

K. Schwärzel

Thünen Institute of Forest Systems, Eberswalde, Germany

e-mail: kai.schwaerzel@thuenen.de
} 
the modern challenges. In this chapter, we discuss two cases in Tanzania: one on the traditional use of compost in the Kagera region (Great African Rift Valley) and another about adapted practices to produce compost manure in the Morogoro region (Uluguru Mountains). Both cases refer to rainfed, smallholder banana-coffee-based farming systems. To conclude, optimised composting practices enable the replenishment of soil nutrients, increase the capacity of soils to store plant-available nutrients and water and thus, enhance soil fertility and food production in degraded banana-coffee-based farming systems. We further conclude that future research is needed on a) nutrient cycling in farms implementing different composting practices and on b) socio-economic analyses of farm households that do not successfully restore soil fertility through composting.

Keywords African smallholder agriculture - Banana-coffee-based farming systems $\cdot$ Reuse of farm waste $\cdot$ Composting $\cdot$ Soil fertility and conservation

\section{Introduction}

Increasing yield gaps for almost all crops and decreasing food security are exacerbating poverty in rural areas in Sub-Saharan countries (Tittonell and Giller 2013). In many cases, low biomass production results from soil and land degradation, which in turn are driven or accelerated by three factors: firstly, the growing demand for food of an increasing population; secondly, poor soil and land management; and thirdly, the increasing variability of rainfall pattern due to climate change (Masawe 1992; FAO 2017a; Gebrechorkos et al. 2018).

In banana-coffee-based farming systems in mountainous regions in Tanzania, smallholder farming contributes up to $95 \%$ of agricultural production (cf. FAO 2017a). Mountainous regions in Tanzania are densely populated and intensively used to produce banana (mainly fruit banana and plantain, Musa spp.), coffee (mainly Coffea caneophora), maize, roots, tubers, pulses, and legumes. Since the 1960s, agricultural production in these regions has increased, often in unsustainable ways. For instance, omitted fallows, intensive use of woody biomass in threestone fires, missing awareness concerning soil erosion measures, frequent tillage, and lack of composting and mulching have resulted in the exploitation of vegetation, land, and soils. In rural areas of Tanzania, such as the Kagera region, more than $90 \%$ of the rural households' cooking energy relies on firewood (unprocessed woody biomass) and charcoal (processed woody biomass), and improved stoves are not widely utilised (URT 2012). Due to the poor soil and land management, the amount of organic material added to the soils has reduced compared to the soil status in the 1960s and 1990s (Copeland Reining 1967; Touber and Kanani 1996). This led to a reduction of humus content and plant-available soil nutrients and thus, decreasing agricultural production. Since the extraction of biomass is not compensated by measures to improve soil fertility and nutrient recycling, significant degradation of vegetation and soil, and thus, accelerated soil nutrient depletion and 
declining water resources occur in the mid and long terms (Schwärzel et al. 2017). Furthermore, East African countries have experienced increased unreliability in rainfall patterns in the last decade, and future scenarios show that higher temperatures, less rain, and changes in rain pattern are very likely for some regions in Tanzania (Gebrechorkos et al. 2018). Smallholder farmers in mountainous regions in Tanzania, however, depend on rainfed agriculture, and we experienced that only a few farm households have experience with or the capacity of long-term water harvesting to feed the family's demand for drinking water and to irrigate the main farmland. Food production is therefore severely jeopardised.

Traditionally, smallholder farming practices in banana-coffee-based farming systems ensured that a sufficient amount of organic material returns to the soils to produce a thick, dark-coloured, humus-rich, and thus, nutrient-rich topsoil (Copeland Reining 1967; Masawe 1992; Touber and Kanani 1996). As introduced above, unsustainable agricultural practices since the 1960s have led to a continuous reduction in the addition of organic material to the topsoil, and thus, to a reduction of humus content in the soil. With less humus that is able to store and release nutrients, the productivity of these farming systems has diminished. A change in reuse and recycling of organic material from farms is thus needed. Research has shown that the potential of farm waste as a soil fertiliser and soil conditioner is not yet exhausted in banana-coffee-based farming systems because adapted composting practices are not frequently applied (cf. Kimaro et al. 2011). Furthermore, nutrients contained in human excreta are not widely maximised (Krause et al. 2015, 2016). Acknowledging that the traditional use of farm waste successfully built up soil fertility over at least one century and has been reduced in only a few decades, we argue that traditional composting practices will have to play a key role in rebuilding soil fertility in degraded banana-coffee-based farming systems. To transform degraded banana-coffee-based farming systems into sustainable agroforestry or agroecology systems that meet regional and global challenges, the understanding of traditional uses of farm waste is as important as the integration and adaptation of these practices (Gliessman 2015, 2016; FAO 2015, 2017b).

In this chapter, we focus on traditional and adapted composting practices in banana-coffee-based farming systems to highlight the positive properties of organic farm waste as a soil fertiliser and soil conditioner. In the following, we first describe the characteristics of banana-coffee-based farming systems, and secondly, illustrate traditional and adapted composting practices that are typical for these farming systems. Then, we present two cases where these composting practices are applied. The first case introduces the work of the farmer initiative Mavuno Project in the Kagera region in north-west Tanzania (Great African Rift Valley, Lake Victoria Basin; Fig. 8.1). In the Mavuno Project, about 750 smallholder farm families have been trained in implementing adapted composting practices to restore degraded bananacoffee-based farming systems. The second case presents the work of a farmer field school established by the Sokoine University of Agriculture (SUA) in the Uluguru Mountains, in the Morogoro region in central Tanzania (Kimaro et al. 2011). Among the skills trained, farmers learnt how to produce adapted in-situ and on-surface composting. In the discussion, we compare degraded banana-coffee-based farming 


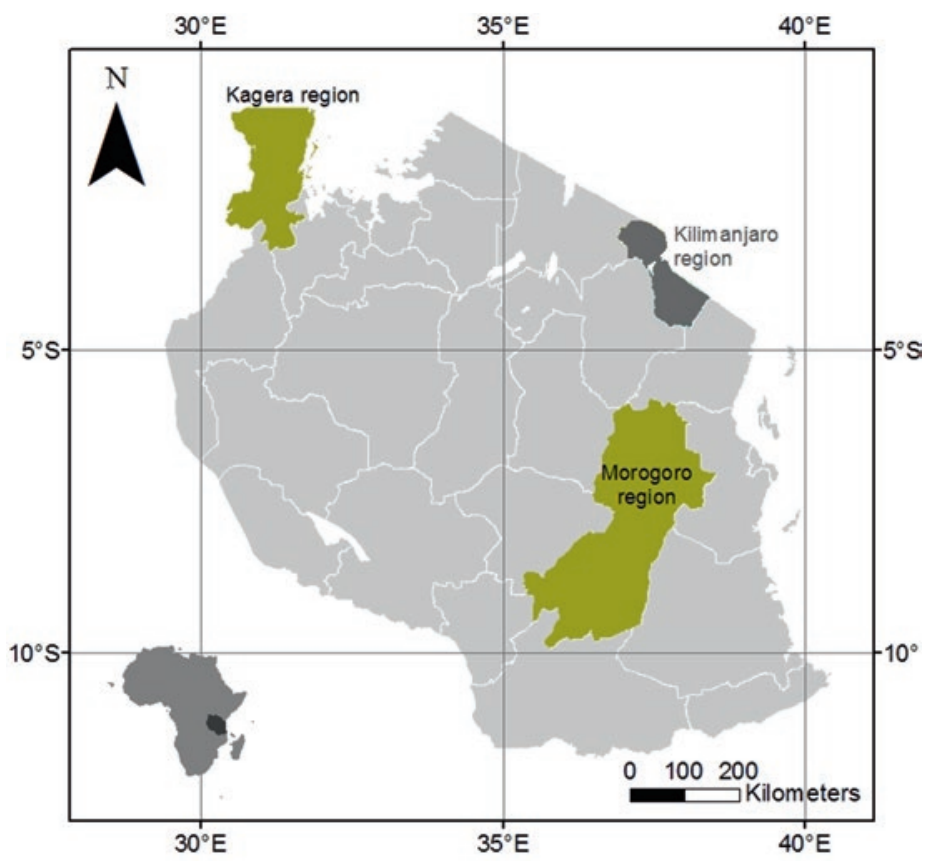

Fig. 8.1 Map of the Kagera, Kilimanjaro, and Morogoro regions in Tanzania. (Vector files used from Map Library 2007)

systems with densely cropped and well-managed systems in the Kilimanjaro region (north Tanzania), discuss the advantages and disadvantages of the composting practices introduced, and consider their limitations.

\section{Banana-Coffee-Based Farming Systems in the Highlands of Tanzania}

The banana-coffee-based farming system is a typical smallholder, usually rainfed, subsistence farming system based on agroforestry in a tropical, mountainous environment, covering the dominant perennial crops coffee and banana, several annual crops, and native trees (Rugalema et al. 1994). Garrity et al. (2012) classified it as a typical Sub-Saharan African farming system, namely, the 'highland perennial', indicating that perennial crops - in this case, banana and coffee - are the core of the agricultural production. In Tanzania, traditional banana-coffee-based farming systems are mostly cultivated by smallholder farmer families and consist of up to four subsystems: the homegarden called Kibanja (in other Bantu languages named 'Kihamba', 'Shamba', or 'Chagga'), new farmland or land in transition from 

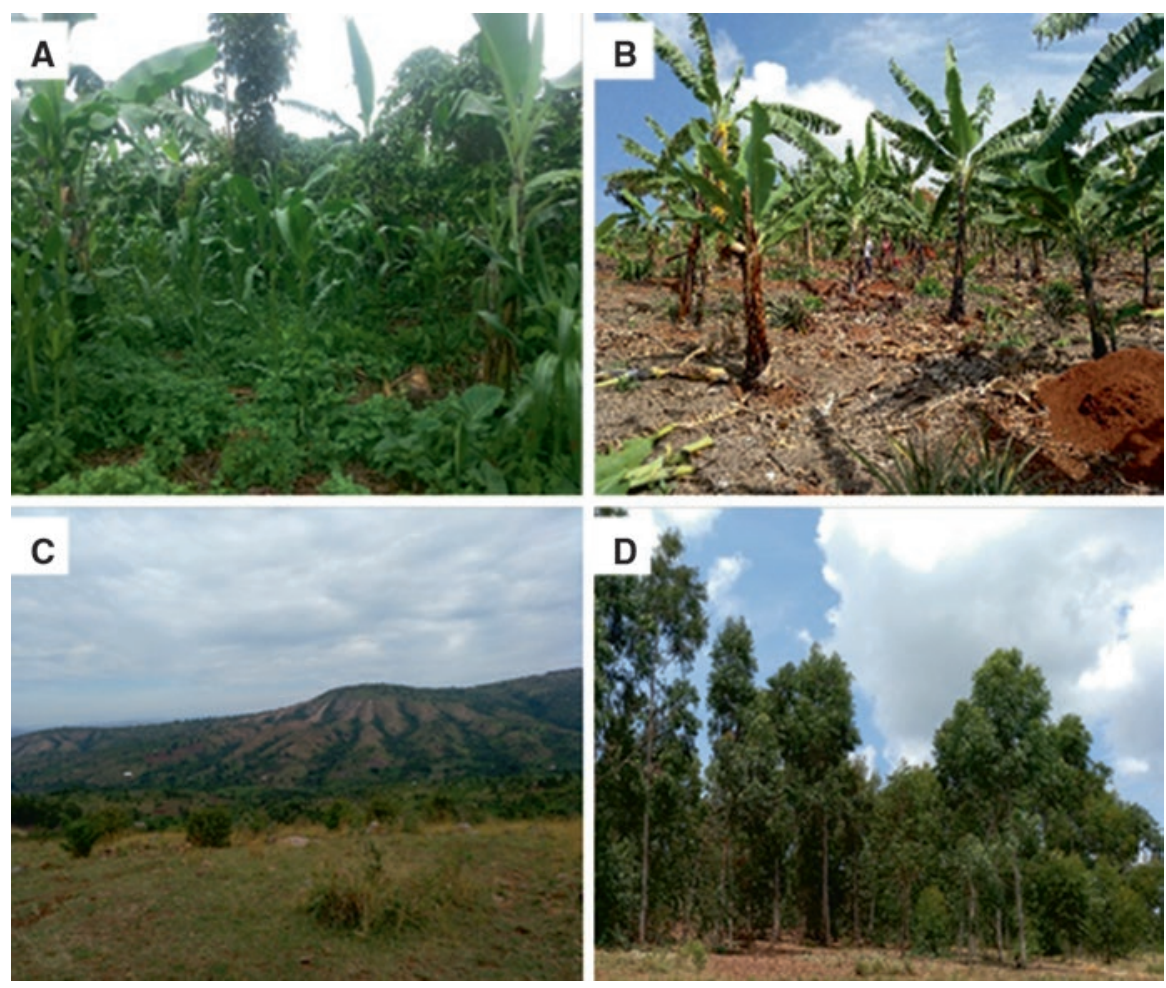

Fig. 8.2 The subsystems of a banana-coffee-based farming system in the Kagera region, northwest Tanzania: (a). Kibanja, (b) Kikamba, (c) Rweya, (d) Kabira

grassland to farmland called the Kikamba, grassland called the Rweya, and woodland, the Kabira (Copeland Reining 1967; Rugalema et al. 1994; Baijukya et al. 2005; Hemp and Hemp 2008; Dancer 2015; Fig. 8.2).

Depending on the region, the naming of these subsystems differs according to the local Bantu language. In the Kilimanjaro region, the banana-coffee-based farming system is known as the Chagga (Hemp and Hemp 2008), named after the dominant tribe, the Chagga, that settled on the slopes of the Mount Kilimanjaro. Chagga landowners create and maintain densely intercropped and productive homegardens known as Kihamba where cultivation is well established. Around the Kihamba a small area is set aside for women to grow a variety of vegetables, which include amaranth, cabbage, peas, and tomatoes. A multilayered vegetation structure (Fig. 8.3), which corresponds to that of a tropical mountain forest with trees, shrubs, and herbs can be found within the Kihamba (Akinnifesi et al. 2008). Comparable to the Kihamba in the Kilimanjaro region, the Kibanja in the Kagera region is the heart of the farming system (Fig. 8.2a). In these fields, which usually are the closest to the 


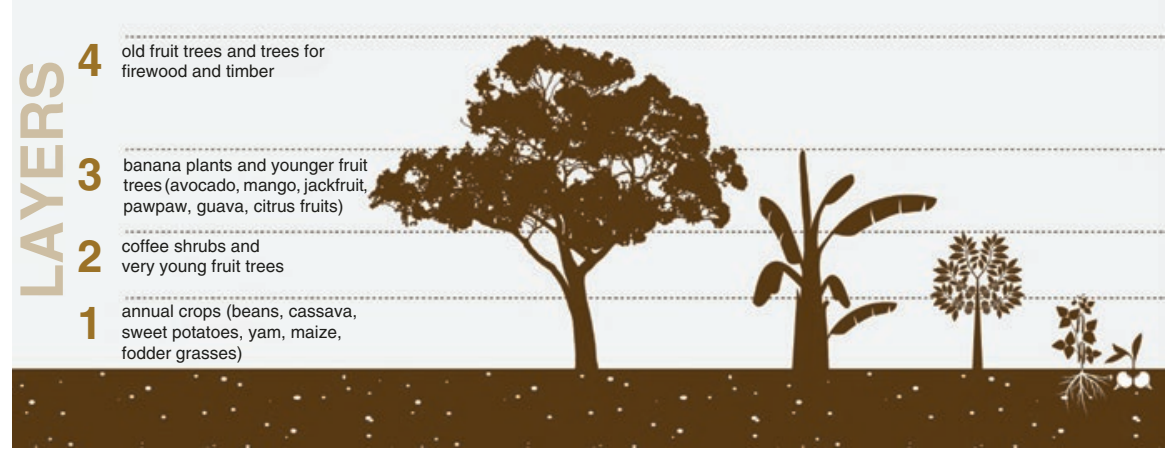

Fig. 8.3 Multilayered vegetation in the traditional banana-coffee-based farming system-the Kibanja or Kihamba -in Tanzania. (Based on Rugalema et al. 1994 and Akinnifesi et al. 2008, Design: Claudia Matthias)

farmers' homes, biomass production is the highest and thus secures the livelihood of the farm families (Copeland Reining 1967; Rugalema et al. 1994).

In very densely cropped homegardens under favourable soil conditions, the vegetation corresponds to that of a tropical mountain forest and consists of multiple layers: annual crops (first layer), coffee shrubs and very young fruit trees (second layer), banana plants and younger fruit trees (third layer), and older trees (fourth layer) (Copeland Reining 1967; Rugalema et al. 1994; Akinnifesi et al. 2008; Hemp and Hemp 2008; Fig. 8.3). The first layer is up to $1 \mathrm{~m}$ high. Here, beneath a canopy of coffee bushes and banana plants, a variety of shade-tolerant annual food crops grow, such as beans, cassava, maize, yams, sweet and Irish potato, and also fodder, herbs, and grass. Coffee, medicinal plants and shrubs, and a few species of young trees are found within the second canopy zone, which lies approximately between a height of 1 and $2.5 \mathrm{~m}$. Less commonly cultivated are the perennial crops vanilla, cotton, and sugarcane. The third vegetation layer, with the banana canopy along with other kinds of fruit and fodder trees, is located above $2.5 \mathrm{~m}$ and approximately reaches a height of $5 \mathrm{~m}$. Here, various banana varieties are grown, of which plantain, the cooking banana is the primary staple food for the farm households; the sweet finger banana is cultivated as a fruit; and the brewing banana to brew local beer. Above this, the fourth layer is less distinct and more blended together. It contains various kinds of trees delivering shade and fruit crops, for example avocado, mango, pawpaw, jackfruit, and citrus fruits, as well as fodder, timber, and firewood. The shade provided by the trees plays an important role in reducing soil evaporation. The response of bananas to droughts is complex; drought effects are associated with low yields notably 6-8 months afterwards. Besides, stall-fed livestock activities and the cultivation of vegetables in kitchen gardens are common practices in this farming system. The farmer families keep mainly goats, pigs, sheep, and chicken in the homegardens, and in a few cases, improved cattle for milk production (Fig. 8.4). 

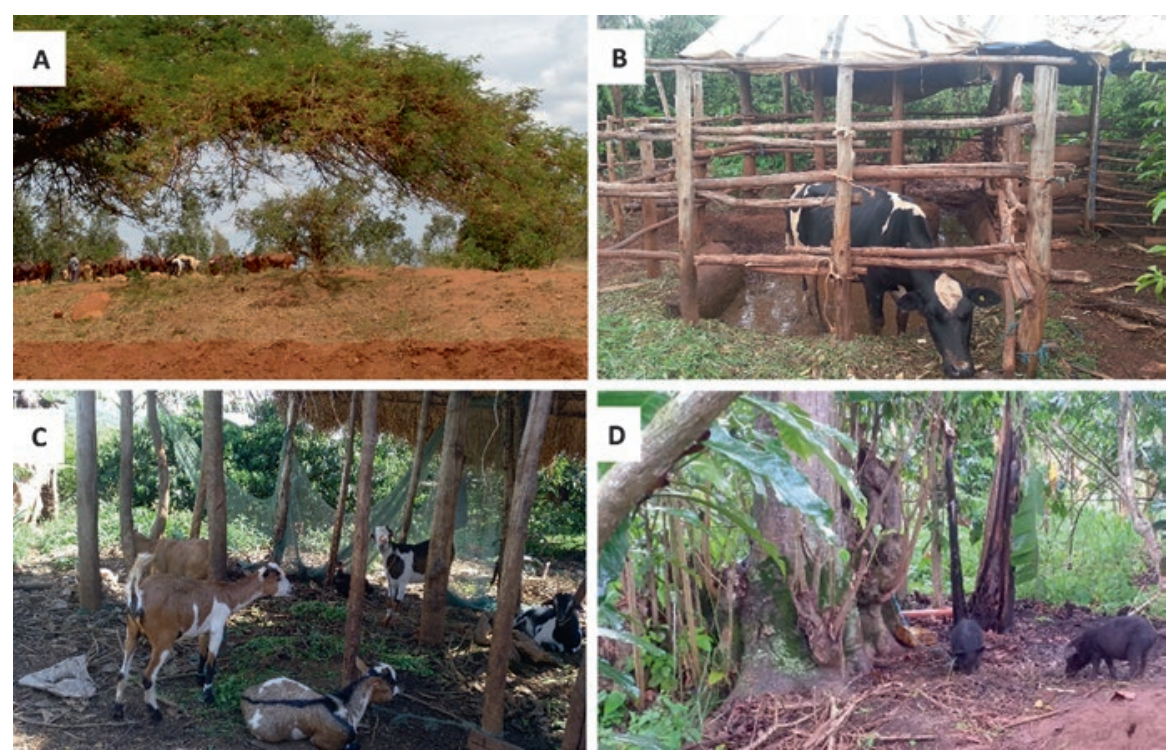

Fig. 8.4 Livestock rearing in smallholder farming: (a) traditional, free-range indigenous cattle in the Rweya, (b) integrated livestock management with cowshed for improved cattle in the Kibanja, (c) tied goats under a roof in the Kibanja, (d) free-range pigs in the Kibanja

As local weather conditions vary, several combinations of water-harvesting practices can be considered in agricultural production. In the Kagera region, for example, some farmers gather rainwater in clay containers from the roofs of their houses to irrigate the kitchen gardens, whereas a series of interlinked canals carrying water harvested in the forest on Mount Kilimanjaro, called mfongo, helps irrigate the homegardens of the Chagga people in the Kilimanjaro region. There, the canals deliver a convenient source of water for domestic use as well as for irrigation purposes. As coffee and banana require between 900 and $1050 \mathrm{~m}^{3}$ water ha ${ }^{-1}$ month $^{-1}$ (Baulme 1993), irrigation water is supplied via the canals at intervals of 5-8 weeks, in the case of insufficient rainfall.

The other three subsystems are less fertile and diverse. The Kikamba (Fig. 8.2b) refers to land transitioning from Rweya towards Kibanja (cf. Baijukya 2004). The original vegetation is gradually replaced by young banana seedlings and some annual crops. Very often, the soils are uncovered and particularly exposed to soil erosion. The Rweya (Fig. 8.2c) is grassland and shrubland, which are often used for free-range livestock-rearing (Fig. 8.4). Traditionally, livestock rearing is an essential strategy against food shortage in dry seasons and an additional source of income (Lichtfield and McGregor 2008). The fourth subsystem is the Kabira (Fig. 8.2d), a land parcel with trees for firewood, charcoal, and timber production (Copeland Reining 1967). 


\section{Composting Practices}

In the banana-coffee-based farming system, the following kinds of organic farm waste are produced: crop residues, livestock urine and manure, kitchen and food waste, litter, dead wood, ashes (inorganic), animal bones, and human urine and faeces; however, not all kinds of farm waste are used to produce compost, particularly not human excreta (Krause et al. 2015, 2016). Since open defaecation is prohibited, human excreta are collected in pit latrines, which are not sealed at the bottom and from which the excreta can easily leak into the underlying groundwater aquifer. Human excreta or pit latrine sludge is not redistributed to the fields. The subsystems of a banana-coffee-based farming system play an essential role in the composting process because farm waste and biomass (grass and wood) - and thus, plant nutrients-circulate within the Kibanja and also between Kibanja, Kikamba, Rweya, and Kabira (Fig. 8.5).

In general, in the Kibanja, most parts of the farm waste usually return to the crop fields, except human excreta, which is gathered in pit latrines on the Kibanja land

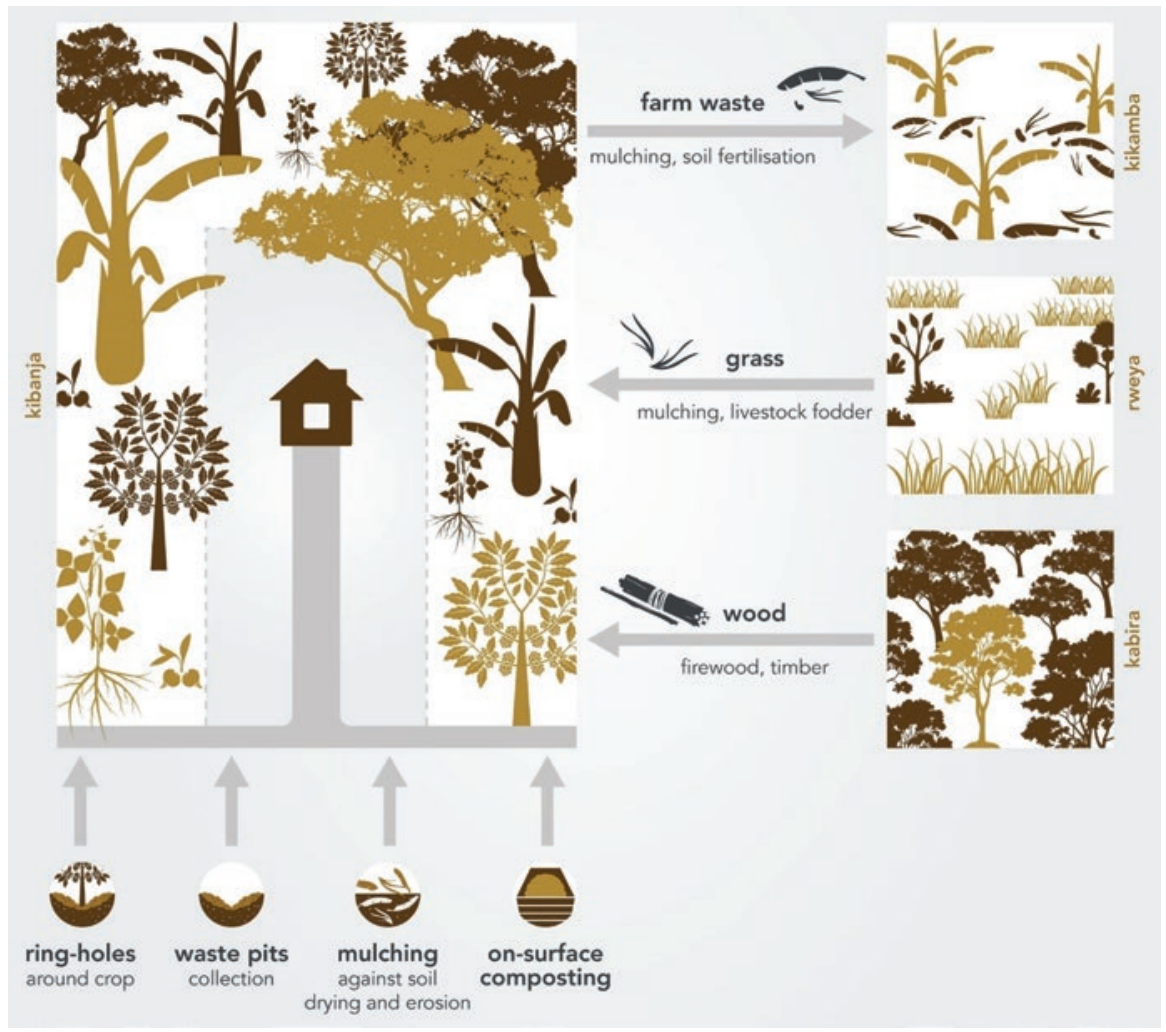

Fig. 8.5 Flows of significant farm waste, grass, and firewood in traditional banana-coffee-based farming systems. (Based on Baijukya and Steenhuijsen Piters 1998), Design: Claudia Matthias 
and is not reused. To fertilise the Kikamba land and to protect its topsoil against erosion, farmers remove organic material originating from the Kibanja and add it to the soils of the Kikamba land. From the Rweya, grass and firewood are imported to the Kibanja. The grass is either used as fodder or as mulch. Leftovers of the burnt firewood usually stay in the Kibanja. Wooden biomass is imported from the Kabira into the Kibanja and leftovers of the use of wooden biomass usually stay in the Kibanja.

\subsection{Traditional Practice: In-Situ and Pit Composting}

In the Kibanja, different practices of composting have been developed over the centuries and are still applied by most of the smallholder farmers (Reetsch et al. 2020a). The primary practices of traditional composting are ring-hole composting, in-situ composting, and pit composting (Fig. 8.6). As indicated in Fig. 8.6a, farmers dig ring-holes around perennial crops, fill them with nutrient-rich farm waste, preferably livestock manure, and cover the filled plots with soil material (ibid.). Another way of composting is presented in Fig. 8.6b. In-situ composting comprises of farm waste, which remains in place or can be spread over the surface and left to decompose itself, without any amendments like layering, watering, or adding of ashes (Kimaro et al. 2011; Reetsch et al. 2020a). During the rotting process of the mulch, humus is accumulated in the topsoil. A third form of reusing farm waste is pit composting (Fig. 8.6c). Very often, farmers collect different kinds of farm waste in pits (Reetsch et al. 2020a). After filling these waste pits, they are covered with soil and, if available, grass (ibid.). Then, a new pit is dug. Over time, the farmland is spread with pits containing rotten organic waste material.

In the homegardens of banana-coffee-based farming systems, the farm waste is composted either in situ or in pits (Fig. 8.6). In particular, in-situ composting enables the replenishment of soil nutrients and the conservation of soil moisture throughout the farmland, whereas pit and ring-hole composting improves the soil nutrient status at selected sites.
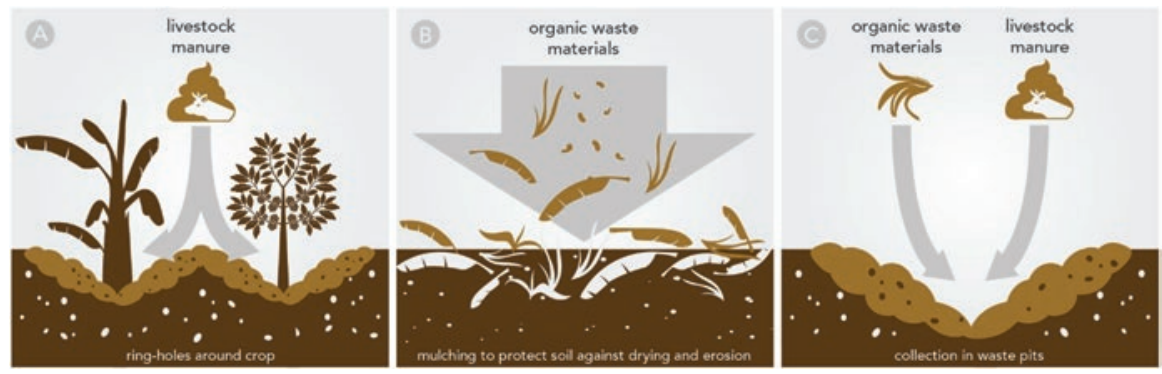

Fig. 8.6 Traditional composting practices in banana-coffee-based farming systems in Tanzania: (a) in-situ composting: ring-hole application of livestock manure around perennial crops (banana, coffee), (b) in-situ composting: crop field mulched with plant-based farm waste, (c) pit composting: farm waste mixed in a waste pit (Design: Claudia Matthias) 


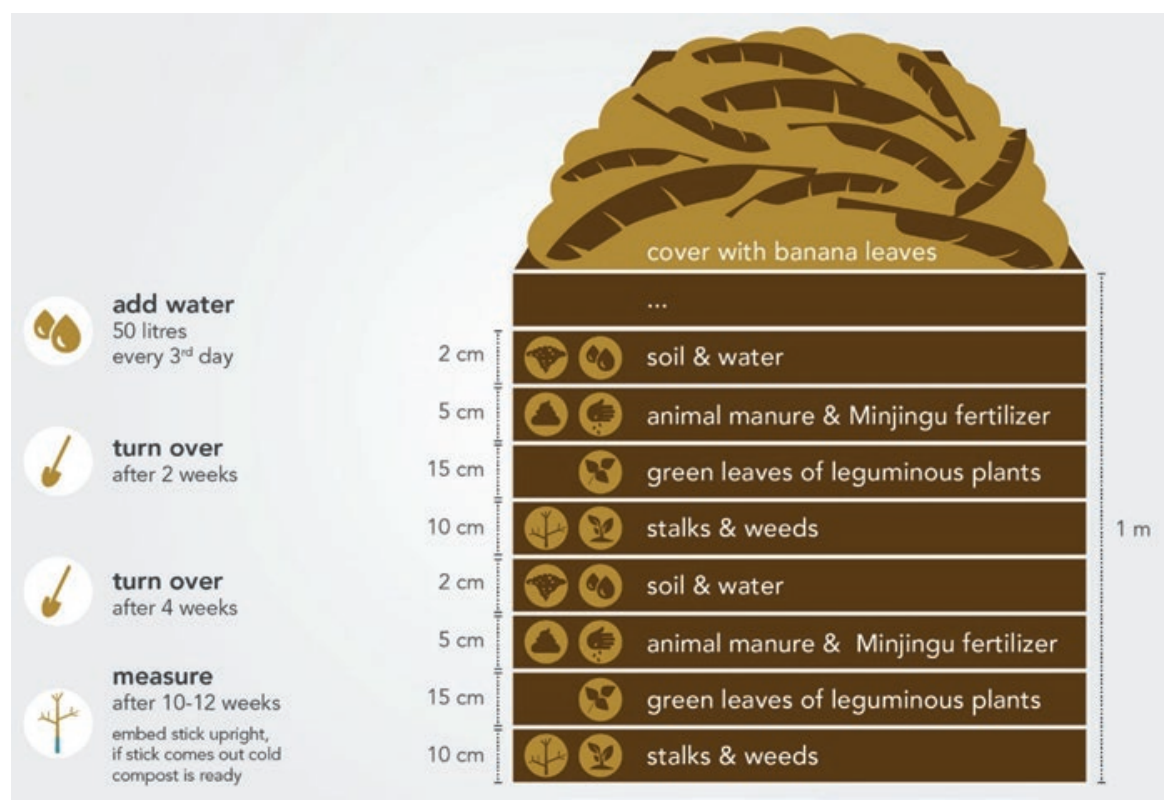

Fig. 8.7 The production of on-surface compost in smallholder farmers in banana-coffee-based farming systems in Tanzania according to Kimaro et al. (2011). (Design: Claudia Matthias)

\subsection{Adapted Practice: On-Surface Composting}

Traditional composting practices have been modified and further developed as onsurface composting (heap method) by Kimaro et al. (2011). This aboveground technique facilitates the production of compost, especially by women and children. The compost pile consists of several layers of farm waste, which are piled on top of each other above the ground (Fig. 8.7). In the first step, the ground is covered with a plastic sheet to avoid leaching, followed by an approximately $10 \mathrm{~cm}$ thick layer of stalks and weed, which forms the base of the compost pile. The second layer consists of green leaves of leguminous plants $(15 \mathrm{~cm}$ in height) to enrich the compost with nitrogen. The third layer preferably contains animal manure and the local, phosphorus-rich Minjingu rock fertiliser ( $5 \mathrm{~cm}$ in height) followed by a $2 \mathrm{~cm}$ soil layer that is moistened with water. The Minjungu rock is mined in the north of Tanzania. All four steps are repeated until a height of approximately $1 \mathrm{~m}$ is reached. Finally, the compost pile is covered with banana leaves to control evaporation. To promote the rotting process, the compost pile needs to be regularly turned over. During the rotting process, a wooden stick is pierced through the layers to estimate the core temperature of the compost pile. As long as the rotting process is ongoing, the stick is warm and moist. If it becomes cold and dry, the rotting process is completed. 


\section{Case Studies}

In this section, we present two case studies on composting in smallholder bananacoffee-based farming systems in Tanzania (Fig. 8.1) that follow each composting practice introduced in the previous section. Both cases are from humid to semihumid mountainous regions with steep slopes. The first case is located in the Kagera region and the second in the Morogoro region. Both regions suffer from land degradation caused by human activities and climate change as outlined in the introduction (Masawe 1992; FAO 2017a).

\subsection{Traditional Composting in the Kagera Region}

The Kagera region lies in north-west Tanzania 1,200 $\mathrm{m}$ above sea level (a.s.1.) (Fig. 8.8). The predominant soils are Rhodic and (Anthri-) Humic Ferralsols, Lithic and Mollic Leptosols, Humic Acrisols, Anthri-luvic Phaeozems, and Ferralic Cambisols following the FAO-UNESCO soil classification of 1988 (Touber and Kanani 1996) and recently as Andosols by Krause et al. (2016). With an annual rainfall ranging between 800 and $1,000 \mathrm{~mm}$, falling in two rainy seasons, which allows for two cropping seasons per year. However, changing rainfall patterns were reported to cause harvest shocks in the last two decades (Trærup and Mertz 2011). The soils in the Kagera region degraded due to increased rainfall variability, soil nutrient losses, and deforestation-and thus increased soil erosion (Baijukya and Steenhuijsen Piters 1998; Trærup and Mertz 2011; Wasige et al. 2013; FAO 2017b) — and changed since 1901 from tropical forest, woodland, and savanna, to cropland and pasture (Wasige et al. 2013).

Traditionally, the use of farm waste plays an important role in this region (Copeland Reining 1967; Katoke 1970; Ndege et al. 1995; Touber and Kanani 1996). Over at least one century, farmers continuously added organic plant material and livestock manure to the fields in the homegardens (Copeland Reining 1967). The warm-humid climate conditions of the region are favourable to decompose organic material within a few days or weeks. This promotes the formation of A-horizons in the soil with a thickness of 30 to $40 \mathrm{~cm}$, rich in soil organic matter and plant-available nutrients (Touber and Kanani 1996). Nutrient levels are found to be especially high near the farmers' houses with a decreasing gradient to the borders of the farm (Baijukya and Steenhuijsen Piters 1998). The thickness of the A-horizons decreased over the last five decades because the fields have been intensively used for agricultural production to meet the increasing demand for food and biofuels of the fast-growing and refugee-hosting population (CARE and Overseas 1994; URT 2016, 2018; Fig. 8.9).

The farmer initiative Mavuno Project (https://mavunoproject.or.tz/wp/) has supported smallholder farmer families in restoring degraded traditional banana-coffeefarming systems and further transforming the Kibanja into sustainably intensified 


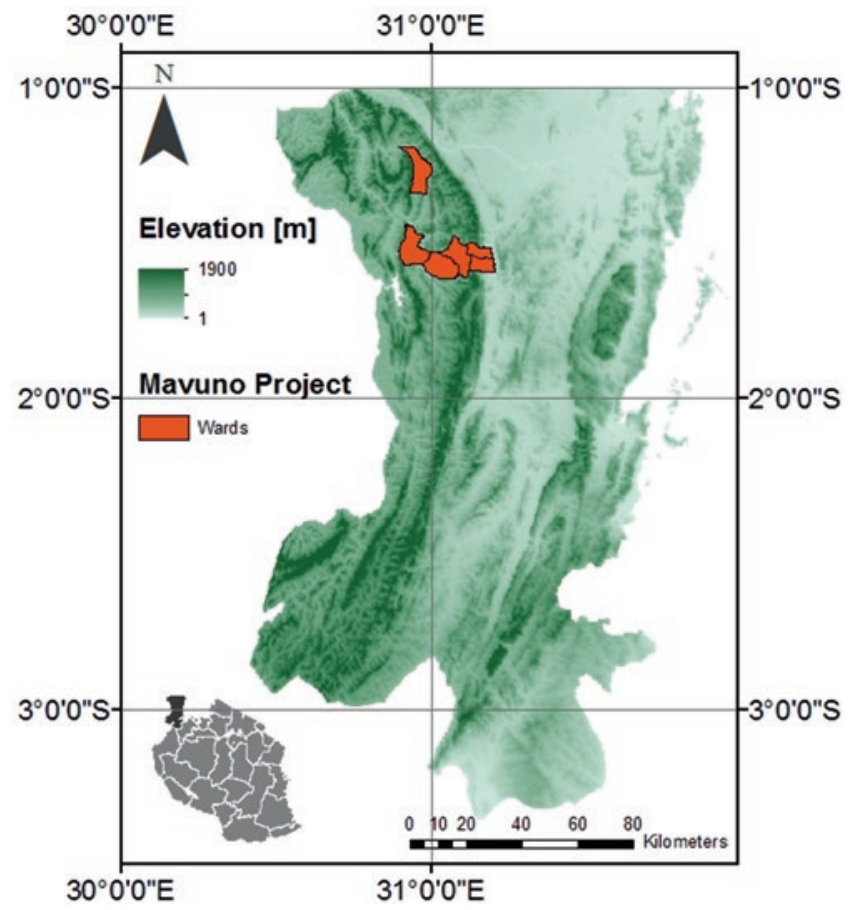

Fig. 8.8 Map of the Kagera region in north-west Tanzania with elevation contours. (Digital Elevation Model used from CGIAR-CSI (2017))

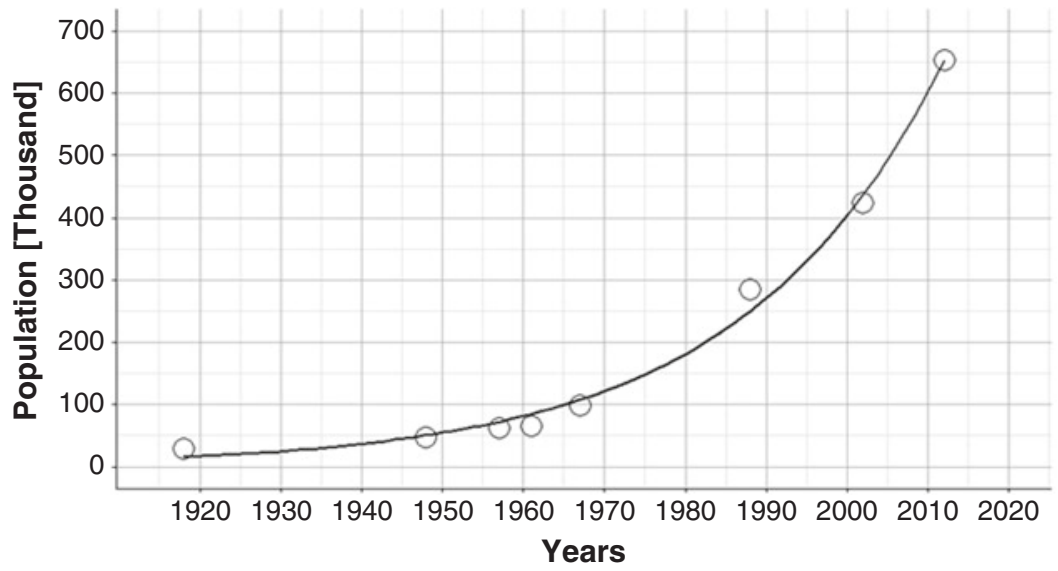

Fig. 8.9 Population growth in Karagwe and Kyerwa districts, Kagera region. (Data extracted from Copeland and Reining (1967), Katoke (1970), and URT (2016)) 
and climate-resistant farming systems. The agricultural transformation was jointly developed with smallholder farmers acknowledging traditional composting practices, involving climate change adaptation measures, and land management practices that are also known in agroforestry (Wekesa and Jönsson 2014; Gliessman 2016; FAO 2017a). These measures involved nutrient management, soil and water conservation, the establishment of mixed crop-tree systems, adapted agricultural practices (crop rotation, intercropping, relay and contour strip cropping), tillage, residue management, integrated livestock management, sustainable energy use, and integrated pest management (Wekesa and Jönsson 2014).

Inspired by this smallholder farmer initiative, we investigated the implementation of traditional and adapted composting practices in five focus group discussions with 22 lead farmers working with the Mavuno Project (Reetsch et al. 2020b). The lead farmers were responsible for training and monitoring of 750 smallholder farm families in the Kyerwa and Karagwe districts (Fig. 8.8) in reintegrating traditional composting practices (Fig. 8.6) and optimising waste flows within the farmland (Fig. 8.5). According to the focus groups, the farm households began by establishing a plot of one acre ( $0.4 \mathrm{ha}$ ) where they planted perennial and annual crops intercropped with a few trees. In this early stage, optimised in-situ composting was already practised. With every rainy season, the plot got more diverse, and farmers started to establish further plots. In the discussions, the lead farmers indicated that soil fertility and biomass production increased in those farm households that implemented the composting practices that they were trained on, whereas they did not increase when a farm household did not properly apply the practices taught. As a side effect, humus enrichment counteracted with soil acidification, protected soil water from evaporation, and markedly reduced soil erosion. Increasing soil fertility led to higher yields and higher food availability for the entire farm household. Harvested crops could be stored either for consumption or for sale. However, the first results also indicated that not all farm households succeed in the same way.

\subsection{On-Surface Composting in the Morogoro Region}

In the Uluguru Mountains in the Morogoro region, the mean annual rainfall varies with altitude, from $900 \mathrm{~mm}$ at $550 \mathrm{~m}$ a.s.l. to $2,300 \mathrm{~mm}$ at more than $1,500 \mathrm{~m}$ a.s.l. In this area, mountain ridges are mainly used for the production of banana, vegetable, bean, and short rain maize while on the foothills long rain maize is the main crop (Kimaro et al. 2005). The topography is highly variable with dissected mountain ridges and foothills with very steep slopes of up to $80 \%$ and narrow valleys (Kimaro et al. 1999). Bedrock geology is dominated by metasediments mainly consisting of hornblende pyroxene granulite, with plagioclase and quartz-rich veins (Kimaro et al. 2005). Based on the FAO (2006), the soils on the mountain ridges are dominantly Endoskeletic and Leptic Cambisols, with accessory surfaces of Haptic and Chromic Phaeozems and Orthi-eutric Regosols. On the foothills, the dominant soils are Chromic Lixisols and Profondic Acrisols associated with Hyperferralic 


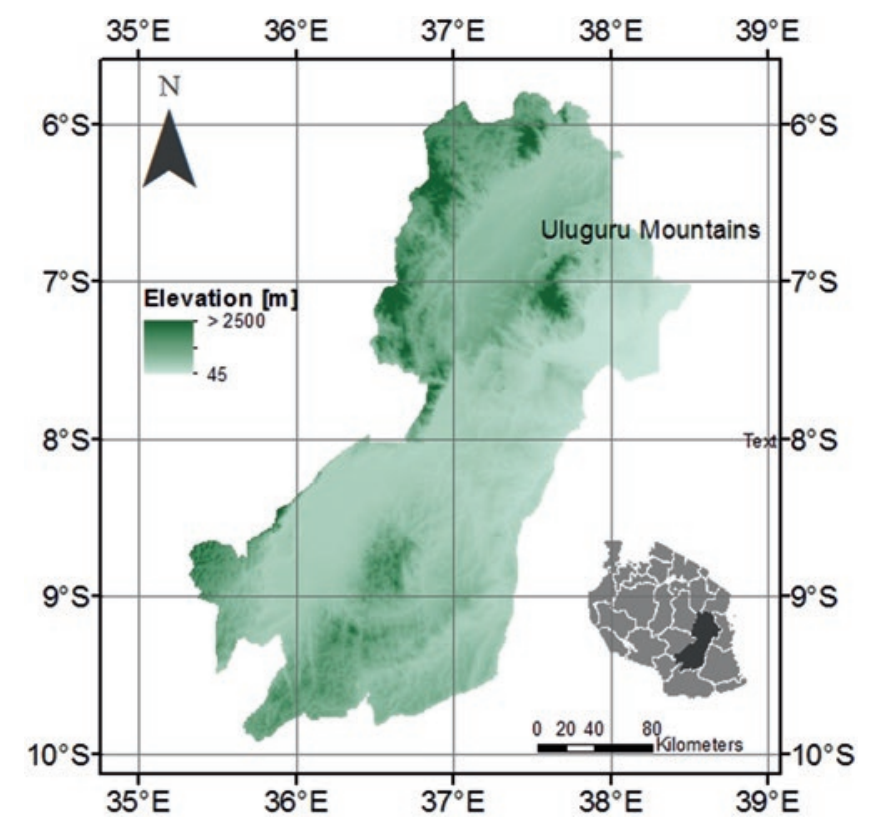

Fig. 8.10 Map of the Morogoro region in central East Tanzania. (Digital Elevation Model used from CGIAR-CSI (2017))

Cambisols and Endoleptic Cambisols. The soil covers are generally affected by severe erosion. Increased free-range livestock and human activity have led to the collapse of the soil conservation system and increased land degradation (including soil erosion). Therefore, strategies that aimed at combating land degradation through mechanical and biological measures such as reforestation activities, agroforestry, protection of watersheds, improved land husbandry, and environmental conservation were initiated in Tanzania in the late 1980s (Shetto 1999, Fig. 8.10).

The Sokoine University of Agriculture (SUA) initiated a soil and water conservation programme in the Uluguru Mountains to train smallholder farmers on the effect of conservational tillage on soil loss and plant nutrient status on their fields. To that end, a farmer field school was piloted in the north-eastern part (Kimaro et al. 2005). The farmers were trained on how to increase the productivity of their farming systems through composting. This included the application of in-situ and on-surface composting in combination with conservation tillage and terracing. The results showed that yields under in-situ composting and conservation tillage were the highest, presumably due to improved soil fertility and decreased soil losses in space and time (Kimaro et al. 2011, Fig. 8.11).

Seasonal yields of vegetable were measured in order to assess the following soil and water conservation practices: (1) conservational tillage and in-situ compositing, (2) traditional terrace and in-situ compositing, (3) conservational tillage and manure, and (4) traditional terrace and manure over traditional farming practices. In this 

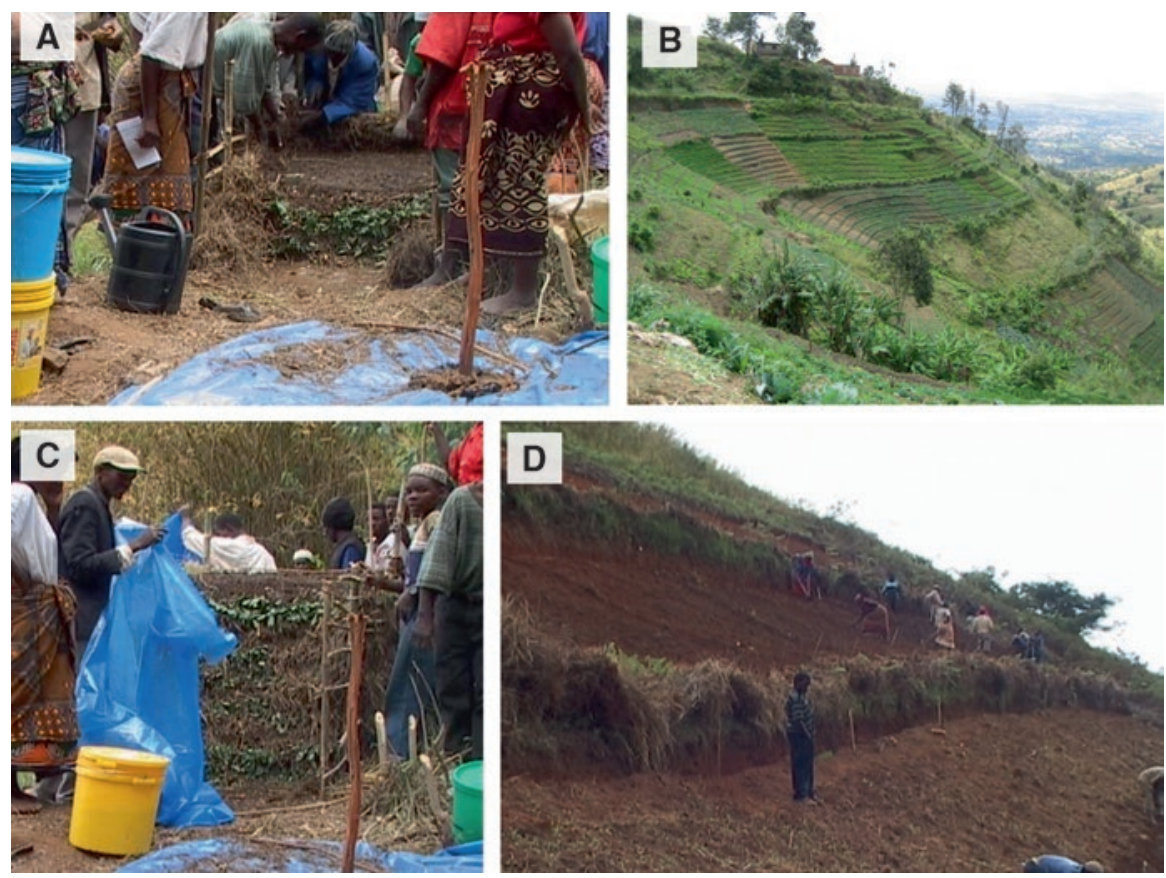

Fig. 8.11 Training farmers on improved indigenous farming practices: (a) and (c) On-surface composting, (b) and (d) Traditional terraces (Kimaro et al. 2011)

case, adapted in-situ composting means a mixture of green manure (a mixture of Gliricidia and other farm residues at a rate of $\left.5 \mathrm{tha}^{-1}\right)$, farmyard manure $\left(10 \mathrm{t} \mathrm{ha}^{-1}\right)$, and Minjingu phosphate rock (MPR) $100 \mathrm{~kg} \mathrm{P} \mathrm{ha}^{-1}$ were left to decompose in situ on the soil (Msita et al. 2010). The results showed that conservation tillage with insitu composting followed by traditional terrace and in-situ composting gave a higher fresh yield of vegetables, presumably due to improved soil fertility and decreased soil losses in space and time, than conservation tillage and livestock manure alone, traditional terrace and manure alone, controlled conservation tillage, and controlled traditional terrace (Msita et al. 2010). It can be concluded for this case that integrating composting practices in conservation tillage for crop production on sloping land is the best practice for sustainable crop production, nutrient availability, and reduction of soil loss.

\section{Discussion}

As evidenced in both cases, adding compost materials to soils enhances the content of soil organic matter and soil nutrients in degraded banana-coffee-based farming systems. The elevated humus levels increased soil fertility and caused an increase in 
yield. In the first case, in the Kagera region, previously productive banana-coffeebased farming systems had deteriorated due to rapid land and soil degradation. The desperate attempt to feed and supply the people (locals and refugees from Rwanda and Burundi) with firewood in the 1990s accelerated the loss of biodiversity, thinned vegetation density and the thick, humus-enriched topsoil. However, through reintegration and optimisation of local traditional composting practices, farmers were able to restore soil fertility and thus, to increase biomass production. In our opinion, degraded banana-coffee-based farming systems could reach a high level of diversity through composting. In contrast, in the banana-coffee-based farming systems of the Kilimanjaro region, however, soil and land degradation had been successfully counteracted by composting for several decades (Hemp and Hemp 2008; Kimaro et al. 2011). There, biodiversity had been highly maintained with a densely grown vegetation structure of four layers and thus agricultural production systems have remained multifunctional (food, biofuels, cash crops, medicine) (cf. Figure 8.3). Degraded homegardens, as presented in the first case in the Kagera region, were less densely cropped with fewer plant species and consisted of only one or two, seldom three vegetation layers (cf. Reetsch et al. 2020a, Figure 8.2). In our opinion, multilayered farming systems in the Kilimanjaro region can be understood as a target state for degraded banana-coffee-based farming systems in the Kagera region (Fig. 8.12).

In both cases, we also observed the challenges and limitations of composting practices. Although composting is often seen as an easily realisable technique, five principles have to be considered to achieve the intended effects (Kimaro et al. 2011; Wekesa and Jönsson 2014; FAO 2015). First, not every farming system produces or

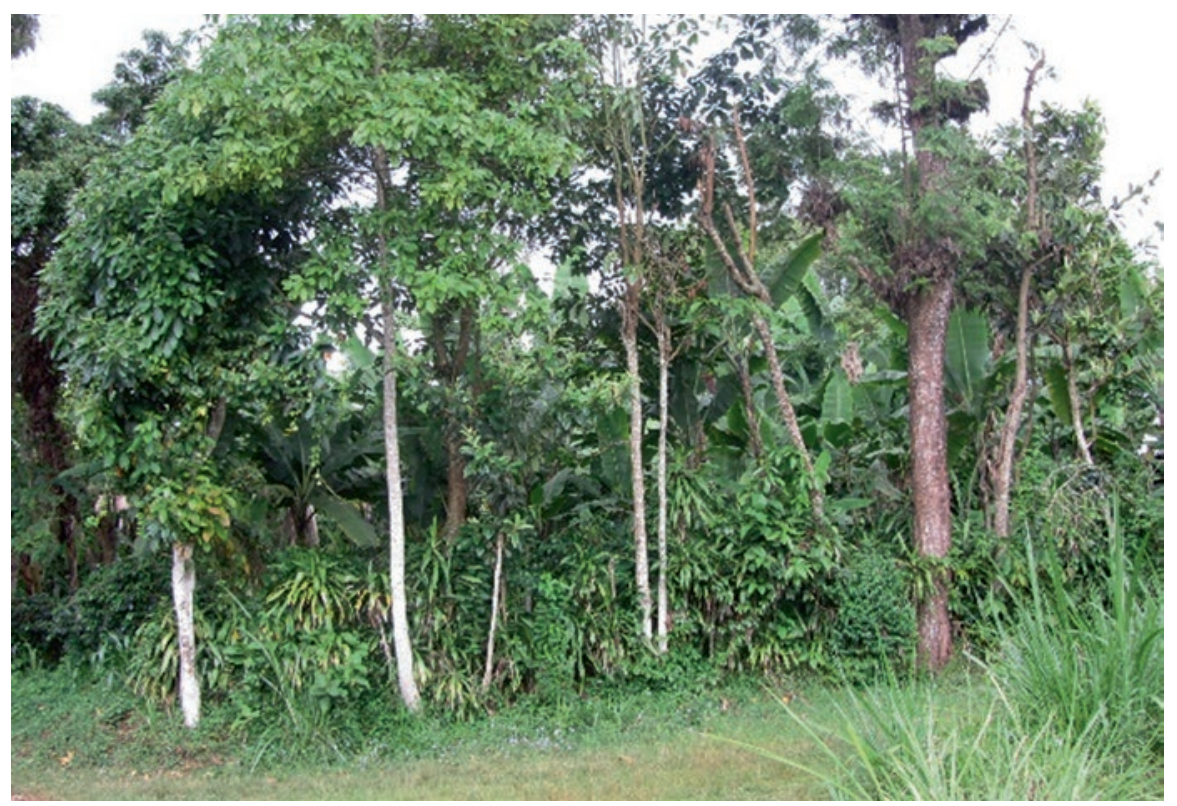

Fig. 8.12 Densely grown Kihamba in the Kilimanjaro region 
needs the same kind of compost. In fact, it depends on the biomass produced in the farming system. Second, the materials to produce compost often compete with other uses, for example, with mulching or livestock feeding. Third, climate/weather conditions strongly control the rotting process through moisture and temperature. If it is too dry or too cold, microorganisms may not properly decompose and transform the organic raw materials. Fourth, collecting farm waste and caring for an ongoing rotting process, which includes several turnovers of the decomposing material, and the application of compost to the crop fields is time and labour-intensive. Fifth, the composition and quantity of plant residues differ among crops and, when used in composting, the nutrient composition of the resulting compost material changes as a result. Besides, the main disadvantage of traditional pit composting is that soils are only punctually enriched with organic matter. The compost material stays in the pit and is not distributed to the crops. As these traditional pits consist mainly of kitchen waste, they are often installed near the farmhouses. Nutrient concentrations are thereby higher in the vicinity of the farmhouses and decrease with increasing distance. However, only numerous rotted waste pits between the crops would bring the soil nutrients to the roots of the crops. Compared to in-situ and pit composting, on-surface composting has clear advantages.

In addition to the challenges mentioned above, water harvesting will play an increasing role in smallholder agriculture under changing climate/weather conditions (Gebrechorkos et al. 2018). Hence, smallholder farmers need to find new strategies to adapt to climate change, not only with regard to soil nutrient recovery but also concerning water harvesting (FAO 2017b).

\section{Conclusion}

The use of farm waste has played a crucial role in traditional smallholder bananacoffee-based farming systems in Tanzania but lost attention since the demand for food and biofuels grew at a faster rate than agricultural production. However, the full potential of farm waste as a fertiliser and conditioner in sustainable soil management is not yet exhausted in traditional smallholder banana-coffee-based farming systems, as composting to our knowledge is not widely practised by all farmers despite efforts to revive it by farmer field schools and other initiatives. In order to keep pace with growing regional and global challenges, traditional composting practices must be adapted and integrated into soil and water conservation strategies (e.g., conservation tillage, terracing, water harvesting). Future research on onsurface composting should, therefore, focus on different compositions and amounts of macro- and micronutrients released from the different kinds of produced composts and should consider the nutrient demand of specific food crops.

We further conclude that future research should also focus on the questions: (1) how flows and stocks of nutrients within a farming system change with newly introduced composting practices (cf. Fig. 8.5); (2) what are the burdens smallholder farmers, that do not successfully restore soil fertility through composting, have to 
cope with; and (3) which further practices, for example as part of agroforestry approaches, need to be considered to transform degraded banana-coffee-based farming systems into long-term sustainable and intensive agricultural systems?

\section{References}

Akinnifesi, F. K., Sileshi, G., Ajayi, O. C., Chirwa, P. W., Kwesiga, F. R., \& Harawa, R. (2008). Contributions of agroforestry research and development to livelihood of smallholder farmers in southern Africa: 2. Fruit, medicinal, fuelwood and fodder tree systems. Agricultural Journal, 3(1), 76-88.

Baijukya, F. P. (2004). Adapting to change in banana-based farming systems of Northwest Tanzania: The potential role of herbaceous legumes. Wageningen: Wageningen University.

Baijukya, F. P., \& Steenhuijsen Piters, B. (1998). Nutrient balances and their consequences in the banana-based land use systems of Bukoba district, Northwest Tanzania. Agriculture, Ecosystems \& Environment, 71(1-3), 147-158.

Baijukya, F. P., de Ridder, N., Masuki, K. F., \& Giller, K. E. (2005). Dynamics of banana-based farming systems in Bukoba district, Tanzania: Changes in land use, cropping and cattle keeping. Agriculture, Ecosystems \& Environment, 106(4), 395-406.

Baulme, R. (1993). Crop water and irrigation requirements: Report to CES. Salzgitter GmbH, Lingen: Consulting Engineers.

CARE and Overseas. (1994). Refugee inflow into Ngara and Karagwe Districts, Kagera Region, Tanzania. Environmental Impact Assessment, London, UK.

CGIAR-CSI. (2017). SRTM 90m digital elevation data. Accessed 11 Oct 2017. http://srtm.csi. cgiar.org/SELECTION/inputCord.asp

Copeland Reining, P. (1967). The Haya. The Agrarian system of a Sedentary people. $\mathrm{PhD}$ thesis, The Faculty of the Social Sciences, Department of Anthropology, The University of Chicago, Chicago, Illinois, USA.

Dancer, H. (2015). Women, land and justice in Tanzania. Eastern Africa series, James Currey.

FAO. (2006). World reference base for soil resources: A framework for international classification, correlation, and communication (Vol. 103: World soil resources reports), Rome: Food and Agriculture Organization of the United Nations (FAO).

FAO. (2015). Agroecology for food security and nutrition. In Proceedings of the FAO International symposium, Rome, Italy.

FAO. (2017a). Agricultural transformation in Africa. The role of natural resources. Nature \& Faune (31st ed.). Accra, Ghana.

FAO. (2017b). Sustainable land management (SLM) in practice in the Kagera Basin: Lessons learned for scaling up at landscape level. Results of the Kagera Transboundary Agroecosystem Management Project (Kagera TAMP) 1(st ed.). Food and Agriculture Organization of the United Nations, Rome, Italy.

Garrity, D., Dixon, J., \& Boffa, J.-M. (2012). Understanding African farming systems. Science and Policy Implications.

Gebrechorkos, S. H., Hülsmann, S., \& Bernhofer, C. (2018). Changes in temperature and precipitation extremes in Ethiopia, Kenya, and Tanzania. International Journal of Climatology, 4(2), 1-13.

Gliessman, S. R. (2015). Agroecology: The ecology of sustainable food systems. Boca Raton: CRC Press.

Gliessman, S. R. (2016). Transforming food systems with agroecology. Agroecology and Sustainable Food Systems, 40(3), 187-189.

Hemp, C., \& Hemp, A. (2008). The Chagga Homegardens on Kilimanjaro. Diversity and refuge function for indigenous fauna and flora in anthropogenically influenced habitats in tropi- 
cal regions under global change on Kilimanjaro, Tanzania. In IHDP, Mountainous Regions: Laboratories for adaptation: Magazine of the International Human Dimensions Programme on Global Environmental Change, IHDP Update, Issue 2, IHDP, Bonn, Germany, pp. 12-17.

Katoke, I. K. (1970). The making of the Karagwe Kingdom. The historical Association of Tanzania, Dar es Salaam, Tanzania.

Kimaro, D. N., Kilasara, M., Noah, S. G., Donald, G., Kajuri, K., \& Deckers, J. A. (1999). Characteristics and management of soils located on specific landform units in the northern slopes of Uluguru Mountains, Tanzania, SUA. In Proceedings of the Fourth annual conference of the faculty of agriculture on agricultural research challenges for the 21st century, Morogoro, Tanzania, Sokoine University of Agriculture (SUA), Morogoro, Tanzania.

Kimaro, D. N., Deckers, J. A., Poesen, J., Kilasara, M., \& Msanya, B. M. (2005). Short and medium-term assessment of tillage erosion in the Uluguru Mountains, Tanzania. Soil and Tillage Research, 81(1), 97-108.

Kimaro, D. N., Terengia, S., Kihupi, N. I., Mtakwa, P. W., Poesen, J., \& Deckers, J. (2011). Conservation agriculture in the highlands of Tanzania under a Coffee-Banana-Agroforestry Farming System. In Training Manual for Small Scale Farmers, Conservation Agriculture for a Restored Environment (NSSCP-CARE) Project, Morogoro, Tanzania.

Krause, A., Kaupenjohann, M., George, E., \& Koeppel, J. (2015). Nutrient recycling from sanitation and energy systems to the agroecosystem- ecological research on case studies in Karagwe, Tanzania. African Journal of Agricultural Research, 10(43), 4039-4052.

Krause, A., Nehls, T., George, E., \& Kaupenjohann, M. (2016). Organic wastes from bioenergy and ecological sanitation as a soil fertility improver: A field experiment in a tropical andosol. The Soil, 2(2), 147-162.

Lichtfield, J., \& McGregor, T. (2008). Poverty in Kagera, Tanzania: Characteristics, causes and constraints. Brighton, UK.

Map Library. (2007). Africa and Tanzania, Shapefile.

Masawe, J. L. (1992). Farming systems and agricultural production among small farmers in the Uluguru Mountain area, Morogoro region, Tanzania. African Study Monographs, 13(3), 171-183.

Msita, H. B., Mtakwa, P. W., Kilasara, M., Kimaro, D. N., Msanya, B. M., Ndyetabula, D. K., Deckers, J. A., \& Poesen, J. (2010). Effect of conservational tillage on soil loss and plant nutrient status on vegetable yield, Northern Slopes of Uluguru Mountains, Morogoro, Tanzania. Paper presented at Proceedings of the workshop on information sharing among soil and water management experts from SADC Universities.

Ndege, J., Steenhuijsen Piters, B., Nyanga, A., \& Ngimbwa, L. (1995). Diagnostic survey of Karagwe district. Tanzanian-Netherlands Farming Systems Research Project, Lake Zone, Royal Tropical Institute (KIT), Amsterdam, Karagwe District Rural Development Programme, Ari Maruku, Bukoba, Ari Ukiriguru, Mwanza, Amsterdam, Tanzania and The Netherlands.

Reetsch, A., Feger, K.-H., Schwärzel, K., Dornack, C., \& Kapp, G. (2020a). Organic farm waste management in degraded banana-coffee-based farming systems in north-West Tanzania. Agricultural Systems. (accepted).

Reetsch, A., Feger, K.-H., Schwärzel, K., \& Kapp, G. (2020b). Transformation of degraded banana-coffee-based farming systems into multifunctional agroforestry systems - A mixed methods study from NW Tanzania. Agricultural Systems. (under review).

Rugalema, G. H., Okting'ati, A., \& Johnsen, F. H. (1994). The homegarden agroforestry system of Bukoba district, North-Western Tanzania. 1. Farming system analysis. Agroforestry Systems, 26(1), 53-64.

Schwärzel, K., Zhang, L., Avellan, T., \& Ardakanian, R. (2017). The water-soil-waste Nexus in SubSaharan Africa: Potentials for increasing the soil productivity. In R. Lal (Ed.), Encyclopedia of Soil Science. Boca Raton: CRC Press.

Shetto, R. M. (1999). Indigenous soil conservation tillage systems and risks of animal traction on land degradation in Eastern and Southern Africa. In P. G. Kaumbutho \& T. E. Simalenga (Eds.), 
Conservation tillage with animal traction. Animal Traction Network for Eastern and Southern Africa (ATNESA) supported by French Cooperation, Namibia, Harare, Zimbabwe, pp. 67-73.

Tittonell, P., \& Giller, K. E. (2013). When yield gaps are poverty traps. The paradigm of ecological intensification in African smallholder agriculture. Field Crop Research, 143, 76-90.

Touber, L., \& Kanani, J. R. (1996). Landforms and soils of Karagwe District. Karagwe District Council, Karagwe District Rural Development Programme, Karagwe, Kagera region, Tanzania.

Trærup, S. L. M., \& Mertz, O. (2011). Rainfall variability and household coping strategies in northern Tanzania: A motivation for district-level strategies. Regional Environmental Change, 11(3), 471-481.

URT. (2012). National sample census of agriculture 2007/2008. Regional Report - Kagera Region. Volume Vh, Dar es Salaam, Tanzania.

URT. (2016). Kagera Region: Basic demographic and socio-economic profile. 2012 Population and Housing Census, Kagera Profile.

URT. (2018). Statistic data Tanzania. Statistics for Development, Tanzania National Bureau of Statistics.

Wasige, J. E., Groen, T. A., Smaling, E., \& Jetten, V. (2013). Monitoring basin-scale land cover changes in Kagera Basin of Lake Victoria using ancillary data and remote sensing. International Journal of Applied Earth Observation and Geoinformation, 21, 32-42.

Wekesa, A., \& Jönsson, M. (2014). Sustainable agricultural land management. Vi Agroforestry, Regional Office East Africa, Kenya.

The opinions expressed in this chapter are those of the author(s) and do not necessarily reflect the views of the United Nations University Institute for Integrated Management of Material Fluxes and of Resources (UNU-FLORES), its Board of Directors, or the countries they represent.

Open Access This chapter is licensed under the terms of the Creative Commons Attribution 3.0 IGO license (https://creativecommons.org/licenses/by/3.0/igo/), which permits use, sharing, adaptation, distribution and reproduction in any medium or format, as long as you give appropriate credit to the United Nations University Institute for Integrated Management of Material Fluxes and of Resources (UNU-FLORES), provide a link to the Creative Commons license and indicate if changes were made.

Any dispute related to the use of the works of the United Nations University Institute for Integrated Management of Material Fluxes and of Resources (UNU-FLORES) that cannot be settled amicably shall be submitted to arbitration pursuant to the UNCITRAL rules. The use of the United Nations University Institute for Integrated Management of Material Fluxes and of Resources (UNU-FLORES)'s name for any purpose other than for attribution, and the use of the United Nations University Institute for Integrated Management of Material Fluxes and of Resources (UNU-FLORES)'s logo, shall be subject to a separate written license agreement between the United Nations University Institute for Integrated Management of Material Fluxes and of Resources (UNU-FLORES) and the user and is not authorized as part of this CC-IGO license. Note that the link provided above includes additional terms and conditions of the license.

The images or other third party material in this chapter are included in the chapter's Creative Commons license, unless indicated otherwise in a credit line to the material. If material is not included in the chapter's Creative Commons license and your intended use is not permitted by statutory regulation or exceeds the permitted use, you will need to obtain permission directly from the copyright holder.

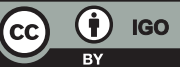

